\title{
Urinary parameters of Trichechus inunguis (Mammalia, Sirenia): reference values for the Amazonian Manatee
}

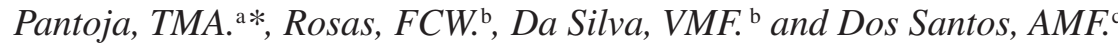 \\ anstituto Natureza e Cultura, Universidade Federal do Amazonas - UFAM, \\ Rua $1^{\circ}$ de maio, s/n, Colônia, CEP 69630-000, Benjamin Constant, AM, Brazil \\ bLaboratório de Mamíferos Aquáticos, Instituto Nacional de Pesquisas da Amazônia - INPA, \\ CP 478, CEP 69011-970, Manaus, AM, Brazil \\ 'Instituto de Hemoterapia do Amazonas - HEMOAM, \\ Av. Constantino Nery, 4397, Manaus, AM, Brazil \\ *e-mail: tatymariucha@gmail.com
}

Received April 16, 2009 - Accepted June 29, 2009 - Distributed August 31, 2010

(With 1 figure)

\begin{abstract}
The Amazonian manatee, Trichechus inunguis (Natterer 1883) is endemic to the Amazon Basin and is currently considered a vulnerable species. In order to establish normality ranges of urinary parameters to help monitor the health of this species in captivity, chemical urinalyses were performed on twelve males and nine females of various age groups. Urine was collected once a month for twelve months in the tanks just after being drained, by placing stainless steel containers under the genital slit of females and applying abdominal massages to males in order to stimulate urination. Quantitative data of glucose, urea, creatinine, uric acid and amylase levels were obtained using colorimetric spectrophotometry. Dip strips were also useful for routine analyses, despite only providing qualitative results. Normal range to glucose levels, regardless of sex or age class, was 3.0 to $3.6 \mathrm{mg} \cdot \mathrm{dL}^{-1}$, coinciding with qualitative values of glucose measured by dip strips. Statistical differences observed in some parameter levels suggest that some urine parameters analysed must take into consideration the sex and the age class of the animal studied, being these differences less remarkable in creatinine and amylase levels. To this last one, statistical difference was detected only in the calve's urine (7.0 to $\left.11.5 \mathrm{mg} \cdot \mathrm{dL}^{-1}\right)$ compared to other age classes samples $\left(4.1\right.$ to $\left.5.3 \mathrm{mg} . \mathrm{dL}^{-1}\right)$. The results presented here may be used as comparative data in future research on urinalysis in related species.
\end{abstract}

Keywords: Trichechidae, aquatic mammals, Sirenian, captivity, urinalysis.

\section{Parâmetros urinários de Trichechus Inunguis (Mammalia, Sirenia): valores-referência para o peixe-boi da Amazônia}

\begin{abstract}
Resumo
O peixe-boi da Amazônia, Trichechus inunguis (Natterer 1883) é endêmico da Bacia Amazônica e é considerado atualmente como espécie vulnerável. Com o objetivo de estabelecer valores de normalidade para os parâmetros urinários com vistas a ajudar no monitoramento da saúde desta espécie em cativeiro, foi realizada urinálise química em doze machos e nove fêmeas de várias classes etárias. A urina era coletada uma vez por mês, durante doze meses, nos tanques, logo após esvaziamento, colocando-se coletores de aço inoxidável sob o orifício genital das fêmeas e aplicando massagem abdominal nos machos para estimular a micção. Dados quantitativos dos níveis de glicose, ureia, creatinina, ácido úrico e amilase foram obtidos por meio de espectrofotometria colorimétrica. O uso de tiras reativas também foi útil para análises de rotina, apesar de somente fornecerem resultados qualitativos. A faixa de normalidade para os níveis de glicose, independente de classe etária e sexo foi de 3,0 a 3,6 mg.dL ${ }^{-1}$, coincidindo com os valores qualitativos identificados pelas tiras reativas. Diferenças estatísticas observadas nos níveis de alguns parâmetros analisados sugerem que estes devem levar em consideração o sexo e a classe etária do animal estudado. Estas diferenças foram menos marcantes nos níveis de creatinina e de amilase, sendo que para esta última foi detectada diferença estatística apenas nas urinas de filhotes lactentes $\left(7,0\right.$ a 11,5 mg.dL $\left.{ }^{-1}\right)$, em comparação às amostras das demais classes etárias (4,1 a 5,3 mg.dL $\left.\mathrm{dL}^{-1}\right)$. Os resultados aqui apresentados podem ser usados como dados comparativos em futuras pesquisas sobre urinálise em espécies relacionadas.
\end{abstract}

Palavras-chave: Trichechidae, mamíferos aquáticos, Sirenia, cativeiro, urinálise. 


\section{Introduction}

The Amazonian manatee (Trichechus inunguis, Natterer, 1883 ) is endemic to the Amazon Basin, and occurs from Marajó Island to headwaters in Colombia, Peru and Equator (Domning, 1981; Best, 1984; Rosas, 1991, 1994).

Historically, the Amazonian manatee has been subjected to strong hunting pressure, and was a source of food not only for indigenous and fishery communities of the Amazonian region, but also a target of large-scale commercialisation throughout the $19^{\text {th }}$ and early $20^{\text {th }}$ centuries (Best, 1984; Rosas and Pimentel, 2001). Although protected by law in Brazil since the $1960 \mathrm{~s}$ (Rosas, 1994), subsistence hunting, and to a lesser degree commercial hunting - both of which persist nowadays - have kept the species among those in a "vulnerable" status (Hilton-Taylor, 2000).

Urinary fluid analysis can be useful in determining the health status of captive animals. In this context, urinalysis could be a useful tool for this purpose, which aims to produce data for the proper monitoring of the health status, to increase knowledge on the physiology of the species, and to provide a scientific foundation for future physiological studies on the Amazonian manatee.

There is little data available on the characterisation, collection and production of urine in aquatic mammals (Bossart et al., 2001), and next to nothing on the composition of the urine of the Amazonian manatee. The only available information on the urine of this species derives from analyses conducted by R. Best (unpublished data) over twenty years ago, with seven captive specimens kept in the Laboratory of Aquatic Mammals (LMA) of the Instituto Nacional de Pesquisas da Amazônia (INPA). This information came from urine collection carried out by Robin Best (in memorian) in captive Amazonian manatees in 1978. These data can be found in LMA's files, and it was possible to access them with the permission of the LMA directorship: Dr. Fernando César Weber Rosas and Dr. Vera Maria Ferreira da Silva. Aiming to continue this basic research for the monitoring of the health condition of these mammals, the present study attempts to determine normal ranges for urinary parameters analysed in the urine of Amazonian manatees in captivity, by means of a comparative analysis between sexes and age classes.

\section{Material and Methods}

All animals analysed in this study were judged to be clinically healthy, based on their general appearance. Within a twelve-month period, 21 animals were sampled - nine females $(\mathrm{F})$ and twelve males $(\mathrm{M})$, classified into the following age classes: calves ( $0-2$ years old/2 $\mathrm{F}$ and $2 \mathrm{M})$, juveniles (3-5 years old/4 $\mathrm{F}$ and $3 \mathrm{M}$ ), subadults (6-9 years old/1 F and $4 \mathrm{M}$ ) and adults (over 10 years old/2 $\mathrm{F}$ and $3 \mathrm{M}$ ).

All juveniles, subadults and adults were kept in three big pools (197 $\mathrm{m}^{3}$ each) and the calves were distributed in four smaller pools $\left(6.4 \mathrm{~m}^{3}\right.$ each). The animals were fed with grass (Brachiaria mutica), lettuce, cabbage and other vegetables at approximately $10 \%$ of their body weight per day. In addition, the calves were nursed by their mothers or fed with an artificial milk formula (Rodriguez et al., 1999).
Urine was collected once a month with the drainage of the tanks, by placing stainless steel containers under the genital slit of females until their urination (Figure 1a). Males were turned on their side and abdominal massages were applied to stimulate micturition (Bossart et al., 2001) (Figure 1b). Only when this latter procedure did not work, the same method employed on females was applied to males.

Urine samples were analysed by colorimetric spectrophotometry after centrifugation at 3,000 rpm for five minutes and then arranged in a Dimension AR (Dade Behring ${ }^{\circledR}$ ) chemical analyser for determination of levels of glucose, urea, creatinine, uric acid and amylase. Qualitative research of glucose in urine samples was conducted with reactive dip strips (URISCAN ${ }^{\mathrm{TM}}$ ), immediately after collecting samples by dipping the strip into fresh urine, and comparing the resulting colors with the standard color scale provided in the kit.

For each parameter, mean (X), standard deviation (SD) and range (maximum and minimum) values were obtained. A $t$-test (0.05) was then applied to check for significant differences between sexes for each age class. Age classes with no significant differences between males and females were then subjected to ANOVA to evaluate statistical differences between each other. Finally, a
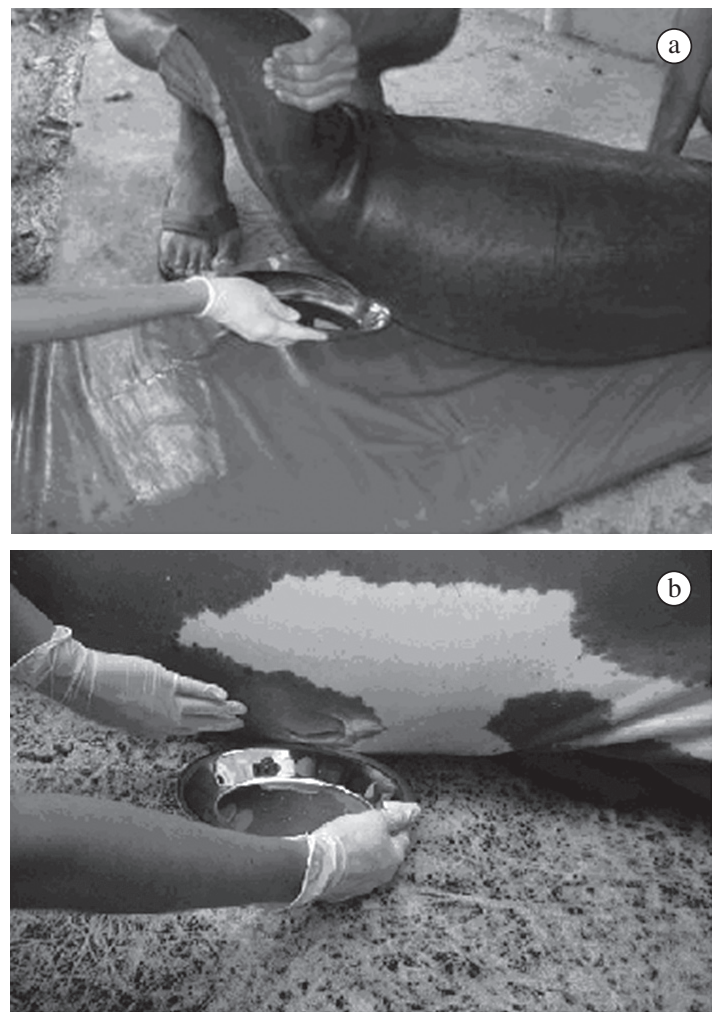

Figure 1. a) Stainless steel containers being placed under the genital slit of female Amazonian manatee until their urination (Photo: Gália Ely de Mattos); b) Urine collection in male Amazonian manatee, turned on its side, and being massaged in its belly to stimulate urination. (Photo: José Anselmo D'Affonseca Neto). 
confidence interval was calculated to groups presenting no significant statistical differences, in order to determine normal ranges for each parameter. Prisma 3.0 software was employed for all statistical analyses.

\section{Results}

Table 1 shows mean (X), standard deviation (SD), and amplitude values for glucose, urea, creatinine, uric acid and amylase values measured in male and female Amazonian manatees of different age classes, over a period of twelve months.

\subsection{Glucose}

Glucose levels did not show significant differences $(\mathrm{P}>0.05)$ between the sexes in different age classes (calves: $\mathrm{t}=2.226, \mathrm{p}=0.0531, \mathrm{n}=34$; juveniles: $\mathrm{t}=0.7640$, $\mathrm{p}=0.4500, \mathrm{n}=97$; subadults: $\mathrm{t}=2.085, \mathrm{p}=0.0611$, $\mathrm{n}=60$; adults: $\mathrm{t}=1.384, \mathrm{p}=0.1795, \mathrm{n}=60$ ). Nor did age classes reveal any significant difference $(\mathrm{P}>0.05)$ between them $(\mathrm{F}=0.9245 ; \mathrm{p}=0.4295 ; \mathrm{n}=251)$. Due to the lack of significant differences in glucose levels between sexes and between age classes, the confidence interval spanned over the data of all individuals, independently of sex or age class (Table 2). Throughout the experiment, glucose level evaluations with reactive dip strips recorded minimum glucose values detectable by such strips $\left(<100 \mathrm{mg} . \mathrm{dL}^{-1}\right)$, in both sexes and regardless of age class.

\subsection{Urea}

Urea levels for calves and subadults showed significant differences $(\mathrm{P}<0.05)$ between sexes $(\mathrm{t}=3.023, \mathrm{p}=0.0144$, $\mathrm{n}=34$; and $\mathrm{t}=4.288, \mathrm{p}=0.0013, \mathrm{n}=60$, respectively), while juveniles $(\mathrm{t}=0.02532, \mathrm{p}=0.9799, \mathrm{n}=97)$ and adults $(\mathrm{t}=1.327, \mathrm{p}=0.1974, \mathrm{n}=60)$ did not reveal significant differences $(\mathrm{P}>0.05)$ between males and females. However, these latter age classes showed significant differences $(\mathrm{P}<0.05)$ between them $(\mathrm{t}=3.555, \mathrm{p}=0.0008, \mathrm{n}=157)$. The confidence intervals calculated considering significant differences between sexes and between age classes are presented in Table 3.

\subsection{Creatinine}

Creatinine levels showed statistical differences $(\mathrm{P}<0.05)$ between sexes only in juveniles $(\mathrm{t}=2.996$, $\mathrm{p}=0.0050, \mathrm{n}=97)$. They did not show significant differences $(\mathrm{P}>0.05)$ between calves, subadults or adults $(\mathrm{F}=3.003$; $\mathrm{p}=0.0526 ; \mathrm{n}=154)$. The confidence interval for urinary creatinine levels obtained separately by age class and by sex, according to statistical differences observed is presented in Table 4.

\subsection{Uric acid}

Uric acid values in juvenile and subadult samples show significant differences $(\mathrm{P}<0.05)$ between sexes $(\mathrm{t}=3.220 ; \mathrm{p}=0.0028 ; \mathrm{n}=97 ;$ and $\mathrm{t}=3.742 ; \mathrm{p}=0.0033$; $\mathrm{n}=60$, respectively). However, in the other age classes (calves and adults), no significant differences $(\mathrm{P}>0.05)$ were observed between male and female values $(t=0.04261$; $\mathrm{p}=0.9669 ; \mathrm{n}=34 ;$ and $\mathrm{t}=1.603 ; \mathrm{p}=0.1226 ; \mathrm{n}=60$, respectively). Moreover, uric acid values in calf and adult samples did not show significant differences $(\mathrm{P}>0.05)$ between them $(t=2.013 ; p=0.0523 ; n=94)$. Confidence interval was thus obtained separately, considering the statistical differences observed (Tabela 5).

\subsection{Amylase}

Amylase levels showed no significant differences $(\mathrm{P}>0.05)$ between sexes in all age classes under analysis (calves $\mathrm{t}=2.255 ; \mathrm{p}=0.0506 ; \mathrm{n}=34$; juveniles $\mathrm{t}=0.1260$; $\mathrm{p}=0.9004 ; \mathrm{n}=97 ;$ subadults $\mathrm{t}=0.2689 ; \mathrm{p}=0.7930 ; \mathrm{n}=60$; and adults $\mathrm{t}=1.935 ; \mathrm{p}=0.0653 ; \mathrm{n}=60)$. However, ANOVA showed significant differences $(\mathrm{P}<0.05)$ between age classes ( $\mathrm{F}=12.50 ; \mathrm{p}<0.0001 ; \mathrm{n}=251)$, and Tukey's a posteriori test resulted in significant statistical differences $(\mathrm{P}<0.05)$ between calves and the remaining age classes. Confidence interval for amylase levels was then calculated considering the significant differences observed (Tabela 6).

\section{Discussion}

\subsection{Glucose}

Glucose, when present in blood in normal levels, is absent in urine, since it is totally reabsorbed in the proximal renal tubules, appearing only as traces in urine (Gürtler et al., 1987; Matos and Matos, 1995; Kantek Garcia-Navarro, 1996). Its appearance in urine occurs when the amount of glucose in the glomerular filtrate exceeds the resorption capability of the tubule (when there is an increase of glucose in blood as a result from diabetes mellitus), or when tubular resorption is insufficient (an actual kidney disease). Anyway, in the event of glycosuria (increased glucose in urine), it is recommended that the glucose levels in the blood of a fasting animal be checked (Matos and Matos, 1995; Kantek Garcia-Navarro, 1996).

Glycosuria can be of either physiological or pathological origin. In the former case, it is usually transitory, and can be either the result of the mere uptake of large quantities of carbohydrate, or instead an instance of the so-called emotional glycosuria, which can happen to forcefully contained animals suddenly releasing adrenalin. According to Kantek Garcia-Navarro (1996), cases of glycosuria have been observed in cats under physical stress, or with a serious bleeding in the bladder. Pathological glycosuria is detectable even in fasting or resting animals, and can indicate any of the following conditions: (1) diabetes mellitus; (2) acute pancreatic necrosis (with the collapse of insulin production causing hyperglycemy and subsequent glycosuria); (3) hyperthyroidism (generating rapid absorption of carbohydrates in the gut); (4) acute renal disease, with deficiency in tubular resorption of glucose; or (5) chronic liver disease, in which this organ is incapable of regulating glycogen reserves (Kantek Garcia-Navarro, 1996). In the case of diabetes mellitus, glucose concentration varies according to the seriousness of the disease, which occurs mainly in aged dogs and cats (Gürtler et al., 1987). 


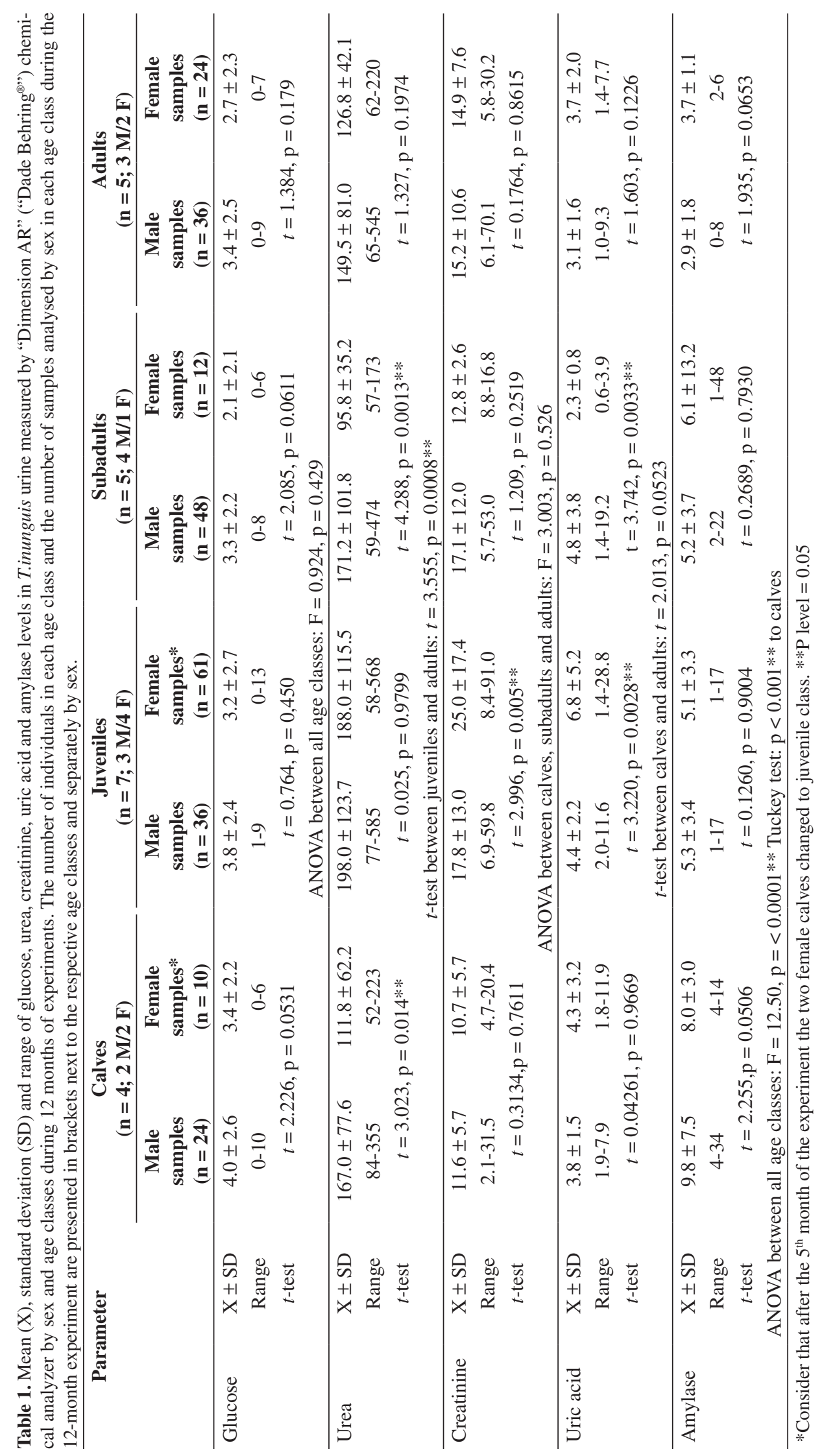


Table 2. Confidence interval of glucose levels measured by "Dimension AR" ("Dade Behring ${ }^{\circledR ”) ~ c h e m i c a l ~ a n a l y s e r ~ i n ~}$ T.inunguis urine ${ }^{1}$

\begin{tabular}{lccccc}
\hline & \multicolumn{4}{c}{ Glucose $\left(\mathbf{m g . d L} \mathbf{L}^{-\mathbf{1}}\right)$} \\
\cline { 2 - 6 } & $\mathbf{n}$ & $\mathbf{C I}-\mathbf{9 5}(\boldsymbol{\%})$ & $\mathbf{C I}+\mathbf{9 5}(\boldsymbol{\%})$ & Range & $\mathbf{X} \pm \mathbf{S D}$ \\
\hline Calves, Juveniles, Subadults and Adults & 251 & 3.0 & 3.6 & $0-13$ & $3.3 \pm 2.5$ \\
\hline $\mathrm{n}=$ number of samples; CI $-95 \%$ and CI $+95 \%$ & $=$ lower and higher confidence intervals, respectively; $\mathrm{X} \pm \mathrm{SD}=$ mean \\
\pm standard deviation.
\end{tabular}

Table 3. Confidence interval of urea levels measured by "Dimension AR" ("Dade Behring ${ }^{\circledR ”}$ ") chemical analyser in male calves, female calves, juveniles, subadult males, subadult females and adults of T. inunguis.

\begin{tabular}{lccccc}
\hline & \multicolumn{5}{c}{ Urea $\left(\mathbf{m g . d L} \mathbf{- 1}^{-1}\right)$} \\
\cline { 2 - 6 } & $\mathbf{n}$ & $\mathbf{C I} \mathbf{- 9 5}(\boldsymbol{\%})$ & $\mathbf{C I}+\mathbf{9 5}(\boldsymbol{\%})$ & Range & X \pm SD \\
\hline Male calves & 24 & 134.1 & 199.7 & $84-355$ & $166.9 \pm 77.6$ \\
Female calves & 10 & 67.3 & 156.3 & $52-223$ & $111.8 \pm 62.2$ \\
Juveniles & 97 & 167.9 & 215.5 & $58-585$ & $191.7 \pm 118.1$ \\
Subadult males & 48 & 141.6 & 200.7 & $59-474$ & $171.2 \pm 101.8$ \\
Subadult females & 12 & 73.4 & 118.1 & $57-173$ & $95.8 \pm 35.2$ \\
Adults & 60 & 122.7 & 158.1 & $62-545$ & $140.4 \pm 68.6$ \\
\hline
\end{tabular}

$\mathrm{n}=$ number of samples; $\mathrm{CI}-95 \%$ and $\mathrm{CI}+95 \%=$ lower and higher confidence intervals, respectively; $\mathrm{X} \pm \mathrm{SD}=$ mean \pm standard deviation.

Table 4. Confidence interval of creatinina levels measured by "Dimension AR" ("Dade Behring ${ }^{\circledR}$ ") chemical analyser in calves, subadults and adults; juvenile males and juvenile females urine of T. inunguis.

\begin{tabular}{lccccc}
\hline & \multicolumn{5}{c}{ Creatinine (mg.dL $\left.\mathbf{m}^{-1}\right)$} \\
\cline { 2 - 6 } & $\mathbf{n}$ & $\mathbf{C I} \mathbf{- 9 5}(\boldsymbol{\%})$ & $\mathbf{C I + 9 5}(\boldsymbol{\%})$ & Range & $\mathbf{X} \pm \mathbf{S D}$ \\
\hline Calves, subadults and adults & 154 & 13.2 & 16.2 & $2.1-70.1$ & $14.7 \pm 9.5$ \\
Juvenile males & 36 & 13.4 & 22.2 & $6.9-59.8$ & $17.8 \pm 13.0$ \\
Juvenile females & 61 & 20.5 & 29.4 & $8.4-91.0$ & $25.0 \pm 17.4$ \\
\hline
\end{tabular}

$\mathrm{n}=$ number of samples; CI $-95 \%$ and CI $+95 \%=$ lower and higher confidence intervals, respectively; $\mathrm{X} \pm \mathrm{SD}=$ mean \pm standard deviation.

Table 5. Confidence interval of uric acid levels measured by "Dimension AR" ("Dade Behring") chemical analyser in calves and adults; juvenile males; juvenile females; subadult males and subadult females urine of T. inunguis.

\begin{tabular}{lccccc}
\hline & \multicolumn{5}{c}{ Uric acid (mg.dL $\left.\mathbf{~}^{-1}\right)$} \\
\cline { 2 - 6 } & $\mathbf{n}$ & $\mathbf{C I} \mathbf{- 9 5}(\boldsymbol{\%})$ & $\mathbf{C I}+\mathbf{9 5}(\boldsymbol{\%})$ & Range & $\mathbf{X} \pm \mathbf{S D}$ \\
\hline Calves and adults & 94 & 3.2 & 4.0 & $1.0-11.9$ & $3.6-1.9$ \\
Juvenile males & 36 & 3.7 & 5.2 & $2.0-11.6$ & $4.4-2.2$ \\
Juvenile females & 61 & 5.4 & 8.1 & $1.4-28.8$ & $6.8-5.2$ \\
Subadult males & 48 & 3.7 & 5.9 & $1.4-19.2$ & $4.8-3.8$ \\
Subadult females & 12 & 1.7 & 2.8 & $0.6-3.9$ & $2.3-0.8$ \\
\hline
\end{tabular}

$\mathrm{n}=$ number of samples; $\mathrm{CI}-95 \%$ and $\mathrm{CI}+95 \%=$ lower and higher confidence intervals, respectively; $\mathrm{X} \pm \mathrm{SD}=$ mean \pm standard deviation.

Table 6. Confidence interval of amylase levels measured by "Dimension AR" ("Dade Behring") chemical analyser in calves, juveniles, subadults and adults urine of T. inunguis.

\begin{tabular}{lccccc}
\hline & \multicolumn{5}{c}{ Amylase (U.L $\left.\mathbf{~}^{-1}\right)$} \\
\cline { 2 - 6 } & $\mathbf{n}$ & $\mathbf{C I} \mathbf{- 9 5}(\boldsymbol{\%})$ & $\mathbf{C I}+\mathbf{9 5}(\boldsymbol{\%})$ & Range & $\mathbf{X} \pm \mathbf{S D}$ \\
\hline Calves & 34 & 7.0 & 11.5 & $4-34$ & $9.2-6.5$ \\
Juveniles, subadults and adults & 217 & 4.1 & 5.3 & $0-48$ & $4.7-4.3$ \\
\hline
\end{tabular}

$\mathrm{n}=$ number of samples; $\mathrm{CI}-95 \%$ and $\mathrm{CI}+95 \%=$ lower and higher confidence intervals, respectively; $\mathrm{X} \pm \mathrm{SD}=$ mean \pm standard deviation. 
Consistently negative results $\left(<100 \mathrm{mg} \cdot \mathrm{dL}^{-1}\right)$ of glucose qualitatively measured by reactive dip strips suggest that expected glucose levels in T. inunguis should be low. Quantitative analysis performed by a Dimension AR (Dade Behring) chemical analyser revealed an amplitude of $0-10 \mathrm{mg} . \mathrm{dL}^{-1}$ in males and $0-13 \mathrm{mg} . \mathrm{dL}^{-1}$ in females (Tabela 1 ). These values are considered very low and confirmed the results obtained by the dip strips. Low levels obtained by both methods refuted the occurrence of glycosuria, and consequently that of related diseases. Results suggest that the application of dip strips in routine urine tests in captive Amazonian manatees can be useful, given the ease, practicality and low cost of this procedure.

Data on Amazonian manatee urinalysis recorded by Best (unpublished data) pointed to the absence of glucose in all tests $(n=13)$ for both males and females. Even if not quantitative, and considering the low variation in diet these animals were subjected to (Cabomba sp. and buffalo grass) as compared to the varied diet offered currently to captive manatees, those data can be said to confirm the low glucose values in the urine of $T$. inunguis as observed in this study (Table. 1). A normal range of urinary glucose obtained for this species (3.0-3.6 mg.dL ${ }^{-1}$ ) (Table 2), can be worked out as a basis for monitoring the health status of captive Amazonian manatees.

\subsection{Urea}

Urea is the main product of protein catabolism in mammals (Gürtler et al., 1987, Storer et al., 2000). It represents almost half of the solid bodies dissolved in urine (Strasinger, 1996). Urea passes through the glomerular coil, and some $25-40 \%$ of the filtered urea is resorbed when going through the proximal and distal tubules. Urea can also be actively secreted in the tubules, contributing to the elaboration of urine (Gürtler et al., 1987), as tubular secretion is important in urine formation (Schmidt-Nielsen, 2003).

Increase in urea excretion can result from (1) febrile diseases; (2) increased uptake of meat by carnivorous and omnivorous animals; or (3) increased neoglycogenesis from proteins. On the other hand, a decrease in urinary urea excretion may indicate liver or kidney disease. An inhibition in urea excretion leads to an increase of nitrogen residues in the blood and consequent uremia (Gürtler et al., 1987). According to Bossart et al. (2001), uremia can result from dehydration, intestinal hemorrhage, septic shock, heart failure or post-release dehydration (speculated in T. manatus latirostris).

Regardless of age class or sex, minimum and maximum values of urea obtained in this study for the Amazonian manatee were lower than those observed by Le Bas (2003) in wild South American fur seals (respectively, 1287.58 and $\left.5894.41 \mathrm{mg} . \mathrm{dL}^{-1}\right)$. This may be due to differences in diet between those species, since fur seals have a protein-rich diet of fish resulting in the elimination of large amounts of urea by their kidneys (Le Bas, 2003), while Amazonian manatees are essentially herbivorous (Best, 1981).
Urea levels in Weddell seals' urine were measured by Kooyman and Drabek (1968). They found 989 mmol.L ${ }^{-1}\left(2772.9 \mathrm{mg} . \mathrm{dL}^{-1}\right)$ in females, and 1013 mmol.L ${ }^{-1}$ (2840.19 mg.dL ${ }^{-1}$ ) in males. Schmidt-Nielsen et al. (1959), also reported high values in seals (Phoca vitulina $L$.) observing mean urinary urea concentration about $671 \mathrm{mmol}^{-\mathrm{L}^{-1}}$ (1881.31 mg.dL ${ }^{-1}$ ) after 24 hour-fasting, that increased to $1026 \mathrm{mmol} . \mathrm{L}^{-1}$ (2876.63 mg.dL $\mathrm{dL}^{-1}$ ) four to eight hours after protein ingestion ( $1 \mathrm{~kg}$ of herring). De Monte and Pilleri (1972) detected higher urea levels than those observed in the present study when analysing the urine from four freshwater dolphins - a male Inia geoffrensis (2038 mg.dL ${ }^{-1}$ ), a male and a female Platanista indi (2292 and $1208 \mathrm{mg} . \mathrm{dL}^{-1}$ ) and a male Platanista gangetica (3182 mg.dL ${ }^{-1}$ ). Such urinary urea levels, compared to those presented here for $T$. inunguis, are also probably due to the high-protein diet of those dolphins. An increase in urea excretion after meat ingestion was also reported in dogs by O'Connor and Summerill (1976), and by Maloiy and Scott (1969) in sheep and red deer under a high-protein diet. Nevertheless, Schweigert (1993) detected lower urea values in the urine of grey seals (Halichoerus grypus) urine, observing $22.1 \mathrm{mg} . \mathrm{dL}^{-1}$ in adult males $(\mathrm{n}=10)$; $30.2 \mathrm{mg} . \mathrm{dL}^{-1}$ in pregnant females $(\mathrm{n}=5) ; 62 \mathrm{mg} . \mathrm{dL}^{-1}$ in lactating females $(\mathrm{n}=22) ; 82.8 \mathrm{mg} \cdot \mathrm{dL}^{-1}$ in calves $(\mathrm{n}=12)$; and $116 \mathrm{mg} \cdot \mathrm{dL}^{-1}$ in juveniles $(\mathrm{n}=5)$. This situation is probably due to a poor nutrient consumption since these animals were submitted to fasting (in reproductive or parental care periods), leading to a decrease of protein catabolism that was reflected in decreasing urinary urea values.

The amplitude of urea values (24-166 mg.dL $\left.{ }^{-1}\right)$ previously observed in the Amazonian manatee (R. Best, unpublished data) was lower than that observed in the present study, regardless of sex or age class (Table 3 ). This is probably due to the less variable diet that the manatees were subjected to at that time.

Le Bas (2003) didn't observe significant differences between urinary variables analysed in wild South American fur seal (Arctocephalus australis) between reproductive classes (immature females, pregnant females, lactating females and immature males), while in our study different urea values recorded between sexes and between different age classes led to the establishment of separate normal ranges according to the statistical differences observed (Table 3).

Urea concentration in serum is a good indicator of the animal nutritional status (Colares et al., 2000), so urine excretion of this compound is also a good marker for the same purpose. All this information leads us to the conclusion that protein ingestion can explain the variations in urea excretion levels in some species that have a normal ingestion of meat, and also probably serve as an explanation for the higher levels observed in samples from calves in this study since - despite T. inunguis being a herbivorous species - calves were submitted to a milk diet, thus to a protein intake too.

Other differences found between age classes could be due to normal differences in food ingestion or in the 
metabolism of those sampled animals. The reference values stipulated in our study serve as information for future studies in urinary urea excretion in this species in order to understand these variations, and also as comparative data for future research in animal urinary health and physiology.

\subsection{Creatinine}

Creatinine is a compound produced from the metabolism of skeletal muscles at a relatively constant rate (Bossart et al., 2001). Apparently, it results from the metabolism of phosphocreatinine, a highly energetic phosphate. Monitoring its excretion is a useful procedure in the study of how the kidney works (Schmidt-Nielsen, 2003), as it undergoes glomerular filtration and is also secreted by the proximal renal tubules (Gürtler et al., 1987).

Studying two males of the Florida manatee, T. manatus latirostris, Manire et al. (2003) reported that levels of creatinine in the serum were affected by a decrease in food ingestion and by differences in the kind of diet. Furthermore, the increase in creatinine levels observed in those animals following the experiment might be due not only to differences in diet, but also to subsequent problems such as a reduction in caloric consumption, dehydration, and immunocompromising. Prior to the analysis of those two Florida manatees, levels of urinary creatinine had shown mean values in the $27.6-52.8 \mathrm{mg} . \mathrm{dL}^{-1}$ range. Such values were higher than those considered normal for T. inunguis in the present study (Table 4). However, a much lower minimum value and a much higher maximum value than those observed in T. manatus latirostris were recorded for T. inunguis (Table 4), probably as a result of multiple environmental factors that distinguish the respective habitats of two species, and also due to normal individual variation. Similarly, as a consequence of differences in diet and in the number of animals analysed, the range values of urinary creatinine observed by Best (unpublished data) in the Amazonian manatee (0.7-4.6 mg. $\left.\mathrm{dL}^{-1}\right)$ was lower than that recorded in the present study. In addition, the higher creatinine values of some juvenil males' urine and of one specific juvenil female (Adana) could be due to the intense muscular activity during urine collection, which always demanded some effort, because of their resistance in being manipulated.

Minimum and maximum creatinine values to Amazonian manatee (2.1 and $91.0 \mathrm{mg} . \mathrm{dL}^{-1}$ ), even considering the statistical differences observed between sexes in juvenile class (Table 4), were lower than those reported to wild South American fur seal (Arctocephalus australis) by Le Bas (2003), which were 2.6 mmol. $\mathrm{L}^{-1}\left(29.41 \mathrm{mg} . \mathrm{dL}^{-1}\right)$ and $46.32 \mathrm{mmol} . \mathrm{L}^{-1}$ (523.98 mg.dL $\mathrm{dL}^{-1}$ ), respectively. This fact can be explained by differences in the kind of alimentation (herbivory or carnivory) of these aquatic mammals.

Normal range stipulated in this study serve not only to monitor urinary creatinine values in T. inunguis, but also as baseline information to future research aiming to elucidate differences observed between urinary creatinine levels in Amazonian manatee and other aquatic mammals, and as comparative data that helps to understand the reason of the variation observed exclusively between sexes in juveniles captive manatees.

\subsection{Uric acid}

Like urea, uric acid is a final product of the metabolism of nitrogen that is excreted by urine. Excretion of uric acid by domestic animals, differently from that by humans, occurs at very low levels. Since the concentration of products of protein metabolism in urine depends on the uptake of food containing nitrogenated substances, it is hardly possible to calculate mean values for various domestic animals (Gürtler et al., 1987).

The amplitude of uric acid values recorded by Best (unpublished data) for T. inunguis (0.1-2.6 mg.dL $\left.\mathrm{dL}^{-1}\right)$ was generally lower than that observed in the present study - lowest value $\left(0.6 \mathrm{mg} . \mathrm{dL}^{-1}\right)$ was observed in a subadult female and highest $\left(28.8 \mathrm{mg} \cdot \mathrm{dL}^{-1}\right)$ in a juvenile female. High levels of uric acid in urine can cause obstruction of the urinary tract by uric acid crystals, a problem that could be avoided by the alkalinisation of the urine and the highest liquid ingestion (Smith, 1981). As for urine alkalinisation, in the present study, reactive strips indicated alkaline $\mathrm{pH}$ for most samples and no specimen exhibited urinary tracts obstructed by uric acid crystals, although one could not assure alkalinisation had prevented such obstruction.

Mean values of uric acid observed by Schweigert (1993) in grey seal (Halichoerus grypus) adult male urine (5.18 mg.dL $\left.{ }^{-1}\right)(\mathrm{n}=10)$ and one calf's $\left(4.97 \mathrm{mg} . \mathrm{dL}^{-1}\right)$ $(n=12)$ were higher than normal values established in this study for Amazonian manatee. However, for grey seal calves $(n=5)$, the mean value $\left(1.68 \mathrm{mg}^{-\mathrm{dL}^{-1}}\right)$ was under normality range stipulated in this study to uric acid levels in T. inunguis of the same age class (Table 5). According to Kaufman et al., 1968 and Paswell, 1974), newborn human babies excrete proportionally a considerable higher amount of uric acid than older children and adults, as a consequence of functional reabsorption immaturity of their renal tubules leading to a higher excretion of this compound in urine, with progressive reduction in this value with age increase (Paswell, 1974).

Notwithstanding, calves and adults sampled in this study didn't present significant statistical differences in uric acid levels excreted in urine. This finding, and the differences between sexes of juveniles and subadults manatees point to the necessity of more research in order to clarify such results.

Normality ranges of uric acid levels in T. inunguis urine presented in this study may serve as a reference in urinalysis diagnosis in captive Amazonian manatees, and as comparative data for future research in uric acid excretion in animal urine.

\subsection{Amylase}

Alfa-amylases are hydrolytic enzymes that turn starch into malthoses. They are produced by different organs: pancreatic amylase is produced by the pancreas and released into the intestinal tract; salivary amylase is synthesised in 
salivary glands and secreted in saliva. Amylase in blood is eliminated by the kidneys and excreted in urine, so an elevation in its seric activity is related to an increase of urinary amylase activity (Lorentz, 1998; Moss and Henderson, 1999; Ravel, 1997). Amylase is an enzyme that acts in complex carbohydrates digestion (Ravel, 1997). This compound is found in the pancreas and other non pancreatic tissues, including the liver, small and large intestines, salivary glands, uterine tube, lungs and heart (Yeo and Cameron, 1999; Cuartero, 2000). Its mean life in serum is about 130 minutes, and its metabolism is through urinary excretion (24\%), and by non-renal mechanism (76\%), maybe by the reticuloendothelial system. Amylase exists in two forms: pancreatic isoamylase $(40 \%)$ and salivary isoamylase $(60 \%)$. An increase in seric amylase and in its urinary excretion does not necessarily mean pancreatic disease and can be due exclusively to an excess of salivary amylase in the case of salivary glands tumors, ovarian tumors or hepatopathies (Reber, 1993).

There is a lack of information about this compound in aquatic mammal urine, and the data provided by this study should be used as comparative information on animal urinalysis. The meaning of the differences in amylase levels observed in calf urine in comparison to other age classes remains unknown but this finding suggest that it may be due to the milk diet of those specimens, which would demand a larger production of amylase to help in their digestion. (Table 6), and not to a possible pancreatic disorder or any other disease mentioned above. Amylase levels reported in this study aim to establish data that could be helpful for future research on the urinary amylase excretion in manatees, given the lack of information on the subject in the literature.

\section{Final Considerations}

Besides the usefulness of monitoring the urinary excretion of glucose, urea, creatinine, uric acid and amylase in T. inunguis, we believe the values recorded in this paper represent normal ranges for those parameters in the urine of the Amazonian manatee urine, since they were taken from no less than 21 animals, with samples collected over twelve months. These results may serve as a reference for diagnosis in the urinalysis of this species in captivity, and as comparative data for future research on health and comparative urinary animal physiology.

Acknowledgements — We would like to thank Dr. Fernando Rosas for his general supervision and financial and logistical resources at the Laboratório de Mamíferos Aquáticos (LMA) in the Instituto Nacional de Pesquisas da Amazônia (INPA), where Dr. Vera Silva was also most helpful. Collection of urine samples could not have been possible without the collaboration of LMA technicians Daniel, Jeová, Marcelo, Nazaré and Raimundo. Those samples were transported to the Fundação Hospital Tropical by Gália Ely de Matos, and analysed by us with the help of Socorro Pontes and Ângela dos Santos. The whole process was photographically documented by José Anselmo D'Affonseca Neto. Horácio Higuchi and Kesa Rosas revised the English manuscript. The last revision was made by Dr. Agno Nonato Serrão Acioli, M. Sc. Fabiane Ferreira de Almeida and Dr. Fernando Scheibe.

\section{References}

BEST, RC., 1981. Foods and feeding habits of wild and captive Sirenia. Mammal Review, vol. 11, no. 1, p. 3-29.

BEST, RC., 1984. The aquatic mammals and reptiles of the Amazon. In: SIOLI, H. (Ed.). The Amazon: limnology and landscape ecology of a mighty tropical river and its basin. Dordrecht: W. Junk. p. 371-412.

BOSSART, GD., REIDARSON, TH., DIERAUF, LA. and DUFFIELD, DA., 2001. Clinical Pathology. In DIERAUF, LA. and GULLAND, FMD. (Eds.). CRC Handbook of Marine Mammal Medicine. 2 ed. Boca Ratón: CRC Press. p. 383-436.

COLARES, EP., COLARES, IG., BIANCHINI, A. and SANTOS, EA., 2000. Seasonal variations in blood parameters of the Amazonian manatee, Trichechus inunguis. Brazilian Archives of Biology and Technology, vol. 43, no. 2, p. 165-171.

CUARTERO, AR., 2000. Hyperamylasemia: it is not always acute pancreatitis. Revista Española de Enfermedades Digestivas, vol. 92 , no. 2, p. 110-1.

DOMNING, DP., 1981. Distribution and status of manatees Trichechus spp. near the mouth of the Amazon River, Brazil. Biological Conservation, vol. 19, no. 2, p. 85-97.

GARCIA-NAVARRO, CEK., 1996. Manual de Urinálise Veterinária. São Paulo: Livraria Varela.

GÜRTLER, H., KETZ, HA., KOLB, E., SCHRÖDER, L. and SEIDEL, H., 1987. Fisiologia Veterinária. 4 ed. Rio de Janeiro: Editora Koogan.

HILTON-TAYLOR, C., 2000. IUCN Red List of Threatened Species. Switzerland: IUCN. Available from: <http://www.iucn. org/redlist/2000>.

KAUFMAN, JM., GREEN, ML. and SEEGMILLER, JE., 1968. Urine uric acid to creatinine ratio: a screening test for inherited disorder of purine metabolism. Journal of Pediatrics, vol. 73, no. 4, p. 583-592.

KOOYMAN, GL. and DRABEK, CM., 1968. Observations on milk, blood, and urine constituents of the Weddell seal. Physiological Zoology, vol. 41, p. 187-194.

LE-BAS, AE., 2003. Renal handling of water, urea and electrolytes in wild South American fur seal (Arctocephalus australis). Latin American Journal of Aquatic Mammals, vol. 2, no. 1, p. 13-20.

LORENTZ, K., 1998. Alfa Amylase. In THOMAS, L. (Ed.). Clinical laboratory diagnostics. Frankfurt: Books Verlagsgesellschaft. p. $192-202$

MALOIY, GMO. and SCOTT, D., 1969. Renal excretion of urea and eletrolytes in sheep and red deer. The Journal of Physiology, vol. 205, no. 1, p. 91-101.

MANIRE, CA., WALSH, CJ., RHINEHART, HL., COLBERT, DE., NOYES, DR. and LUER, CA., 2003. Alterations in blood and urine parameters in two Florida manatees (Trichechus manatus latirostris) from simulated conditions of release following rehabilitation. Zoo Biology, vol. 22, no. 2, p. 103-120.

MATOS, MS. and MATOS, PF., 1995. Laboratório Clínico Médico-Veterinário. 2 ed. Rio de Janeiro: Editora Atheneu. 
MONTE, T. and PILLERI, G., 1972. Hematological, plasmatic and urinary values of three species of cetaceans belonging to the family Platanistidae [Inia geoffrensis (de Blainville, 1817); Platanista indi (Blyth, 1859); and Platanista gangetica (Roxburgh, 1801)]. Revue Suisse de Zoologie, vol. 79, no. 1, p. 235-252.

MOSS, DW. and HENDERSON, AR., 1999. Digestive enzymes of pancreatic origin. In BURTIS, CA. and ASHWOOD, ER. (Eds.). Textbook of Clinical Chemistry. 3 ed. Philadelphia: W.B Saunders Company. p. 689-98.

O'CONNOR, WJ. and SUMMERILL, RA., 1976. The excretion of urea by dogs following a meat meal. The Journal of Physiology, vol. 256 , no. 1 , p. 93-102.

PASWELL, JH., 1974. Fractional excretion of uric acid in infancy and childhood: index of tubular maturation. Archives of Disease in Childhood, vol. 49, no. 11, p. 878-882.

RAVEL, R., 1997. Função pancreática. In RAVEL, R. (Ed.). Laboratório clínico: aplicações clínicas dos dados laboratoriais. 6 ed. Rio de Janeiro: Guanabara Koogan. p. 389-94.

REBER, HA., 1993. Pâncreas. In SCHWARTZ, SI., SHIRES, GT. and SPENCER, FC. (Eds.). Princípios de cirurgia. 6 ed. Rio de Janeiro: McGraw-Hill. p. 1272-1297.

RODRIGUEZ, ZM., SILVA, VMF. and D'AFFONSECA NETO, JA., 1999. Teste de fórmula láctea na alimentação de filhotes órfãos de peixe-boi da Amazônia (Trichechus inunguis). In FANG, TG., MONTENEGRO, OL. and BODMER, RE. (Eds.). Manejo y Conservación de Fauna Silvestre en América Latina. Bolivia: Instituto de Ecología. p. 405-408.

ROSAS, FCW. and PIMENTEL, TL., 2001. Order Sirenia (manatees, dugongs, sea cows). In FOWLER, ME. and CUBAS, ZS. (Eds.). Biology, Medicine, and Surgery of South American Wild Animals. Ames: Iowa State University Press. p. 352-362
ROSAS, FCW., 1991. Peixe-boi da Amazônia, Trichechus inunguis (Natterer, 1883). In CAPPOZZO, HL. and JUNIN, M. (Eds.). Estado de Conservación de los Mamíferos Marinos del Atlántico Sudoccidental. Rome: UNEP. p. 178-181. (Informes y Estudios del Programa de Mares Regionales del Programa de las Naciones Unidas para el Medio Ambiente, no. 138)

ROSAS, FCW., 1994. Biology, conservation and status of the Amazonian manatee Trichechus inunguis. Mammal Review, vol. 24 , no. 2 , p. $49-59$.

SCHMIDT-NIELSEN, B., MURDAUGH, HV., O'DELL JUNIOR, R. and BACSANYI, J., 1959. Urea excretion and diving in the seal (Phoca vitulina L.). Journal of Cellular and Comparative Physiology, vol. 53, p. 393-411.

SCHMIDT-NIELSEN, K., 2003. Fisiologia animal: adaptação e meio ambiente. 5 ed. São Paulo: Livraria Santos Editora.

SCHWEIGERT, FJ., 1993. Effects of fasting and lactation on blood chemistry and urine composition in the grey seal (Halichoerus grypus). Comparative Biochemistry and Physiology: Comparative Physiology, vol. 105A, no. 2, p. 353-357.

SMITH, DR., 1981. General urology. Los Altos: Lange Medical Publications.

STORER, TI., USINGER, RL., STEBBINS, RC. and NYBAKKEN, JW., 2000. Zoologia geral. São Paulo: Companhia Editora Nacional.

STRASINGER, SK., 1996. Urinalysis and body fluids. 3 ed. Philadelphia: F.A. Davis.

YEO, CJ. and CAMERON, JL., 1999. O pâncreas. In: SABISTON JUNIOR, DC. and LYERLY, HK. (Eds.). Tratado de cirurgia: as bases biológicas da prática cirúrgica moderna. 15 ed. Rio de Janeiro: Guanabara Koogan. p. 1072-110. 
